\title{
An experimental model for the study of drug effects on cutaneous healing ${ }^{1}$
}

\author{
Modelo experimental para o estudo de efeitos de drogas sobre a cicatrização cutânea
}

\author{
Antonio Chiquetti Júnior², Marco Aurélio de Freitas Rodrigues ${ }^{3}$, Vinicius Daher Alvares Delfino ${ }^{4}$. \\ 1. Research performed at State University of Londrina (UEL), Paraná, Brazil. \\ 2. M.Sci., Division of Plastic Surgery, Department of Surgery, UEL, Paraná, Brazil. \\ 3. PhD, Division of Urology, Department of Surgery UEL, Paraná, Brazil. \\ 4. PhD, Division of Nephrology, Department of Internal Medicine, UEL, Paraná, Brazil.
}

\begin{abstract}
Purpose: Immunosuppressive agents are known to interfere with the healing of surgical wounds. The increasing use of these drugs warrants a better understanding of their effects on wound healing. The aim of this study was to develop an experimental model that would allow for a reliable and rapid assessment of drug effects on cutaneous wound healing. Methods: Thirty syngeneic Lewis rats underwent surgical incision on their dorsal region, in the presence or absence of a three-week regimen of immunosuppressant drug therapy (i.e., cyclosporin, azathioprine, and prednisone). Surgical site tissue was collected at intervals over 21 days after surgery and analyzed for cell number and collagen fiber content. Both of these quantitative assessments were performed using digital image capture with the Image Pro Plus 4.5 software. Results: Computerized histomorphometric analyses revealed an apparent inhibition of cellular responses and collagen fiber production in drug-treated animals compared to control animals. Conclusion: The experimental model was reproducible, easy to perform, and allowed for quantitative histological evaluations. It may be useful for the study of surgical healing in the presence of other drug classes.
\end{abstract}

Key words: Animal Experimentation. Immunosuppression. Wound Healing. Rats.

\section{RESUMO}

Objetivo: Várias drogas podem interferir no processo de cicatrização de feridas cirúrgicas, incluindo-se aqui agentes imunossupressores. Devido ao crescimento do número de pessoas tratadas com estas drogas, um modelo experimental, baseado em um sistema computadorizado de avaliação histológica, para verificar os efeitos destas drogas sobre a cicatrização cirúrgica pode se mostrar útil e permitir, também, o estudo das ações de outras drogas sobre este processo. Métodos: Trinta ratos Lewis isogênicos foram submetidos a incisões cirúrgicas na região dorsal e metade deles foi imunossuprimida utilizando-se ciclosporina, azatioprina e prednisona por 3 semanas. Em cinco intervalos de tempo pré-fixados, avaliações histológicas quantitativas de células e fibras colágenas dos sítios operatórios de animais tratados e controles foram realizadas, utilizando-se captura digital das imagens por meio do programa Image Pro Plus 4.5. Resultados: A avaliação dos sítios cirúrgicos mostrou, nos animais sob uso de drogas imuossupressoras, aparente diminuição no número de células e na produção de fibras colágenas. Conclusões: $\mathrm{O}$ modelo experimental proposto mostrou-se viável por exigir recursos pouco sofisticados, pela fácil realização e por fornecer avaliações histológicas quantitativas. Este modelo poderá ser utilizado para o estudo da ação de outras classes de drogas sobre a cicatrização cirúrgica.

Descritores: Experimentação Animal. Imunossupressão. Cicatrização de Feridas. Ratos. 


\section{Introduction}

The wound healing process consists of a complex chain of well-characterized events that eventually result in the formation of scar tissue ${ }^{1}$. This process can be influenced by local and systemic factors of collagen fibers, reducing neovascularization, and reducing the epithelialization rate. An increasing number of patients undergo organ transplantation or use immunosuppressive agents for the treatment of other clinical conditions, and both of these growing populations may require elective or emergency surgical treatment. Thus, a better understanding of the effects of immunosuppression on healing is warranted. The objective of the present study was to develop an experimental model that would permit the study of the effects of immunosuppression on cell infiltration and collagen formation associated with cutaneous. In particular, the systemic action of immunosuppressive drugs has been shown to play an important role in wound healing by inhibiting the production healing.

\section{Methods}

Thirty isogenic, male and female adult Lewis rats with a mean weight of $200 \mathrm{~g}$ were supplied by the vivarium of the University Hospital of the State University of Londrina. All animals were allowed free access to food and water throughout the study and were treated in accordance with ethical principles for handling experimental animals ${ }^{2}$. Fifteen animals were randomly assigned into two groups, the treatment or control group. All animals underwent a surgical incision and suture in their dorsal region. Animals in the treatment group also recieved immunosuppressive drug treatment (i.e., cyclosporine, azathioprine and prednisone), while the control group did not. One day prior to surgical incisions (D-1), the dorsal regions were shaved and immunosuppressive drug administration was initiated (treatment group only). On the following day, animals were anesthetized with ethyl ether and received 2-cm long longitudinal incisions in the skin of the dorsal region through the entire thickness of the skin. The incisions were then sutured with separate 5-0 monofilament nylon stitches. The doses of the immunosuppressive agents employed here are similar to those used for the maintenance of human renal transplant patients (i.e., cyclosporin: $5 \mathrm{mg} / \mathrm{kg} / \mathrm{d}$; azathioprine: $2.5 \mathrm{mg} / \mathrm{kg} / \mathrm{d}$; prednisone: $0.33 \mathrm{mg} / \mathrm{kg} / \mathrm{d}$ ). Dilution of all drugs was standardized as follows. One $100 \mathrm{mg}$ cyclosporin gelatin capsule was suspended in $50 \mathrm{ml}$ olive oil (final concentration, $2 \mathrm{mg} / \mathrm{ml}$ ). One $50 \mathrm{mg}$ azathioprine tablet was dissolved in $50 \mathrm{ml}$ of physiological saline (final concentration, $1 \mathrm{mg} / \mathrm{ml}$ ). One $20 \mathrm{mg}$ prednisone tablet was dissolved in $60 \mathrm{ml}$ of physiological saline (final concentration, $0.33 \mathrm{mg} / \mathrm{ml}$ ). Animals received $0.5 \mathrm{ml}$ cyclosporin, $0.5 \mathrm{ml}$ azathioprine, and $0.2 \mathrm{ml}$ prednisone by gavage every morning for three weeks. For drug administration, the animals were sedated with ethyl ether and kept in the vertical position with cervical hyperextension. A specially constructed gavage tube was employed. This metal tube had a slight curvature to facilitate access to the oropharynx and esophagus and an olive-shaped end to prevent damage to the upper digestive tract (Figure 1). The dead space of the tube was measured $(0.5 \mathrm{ml})$ to standardize drug administration.

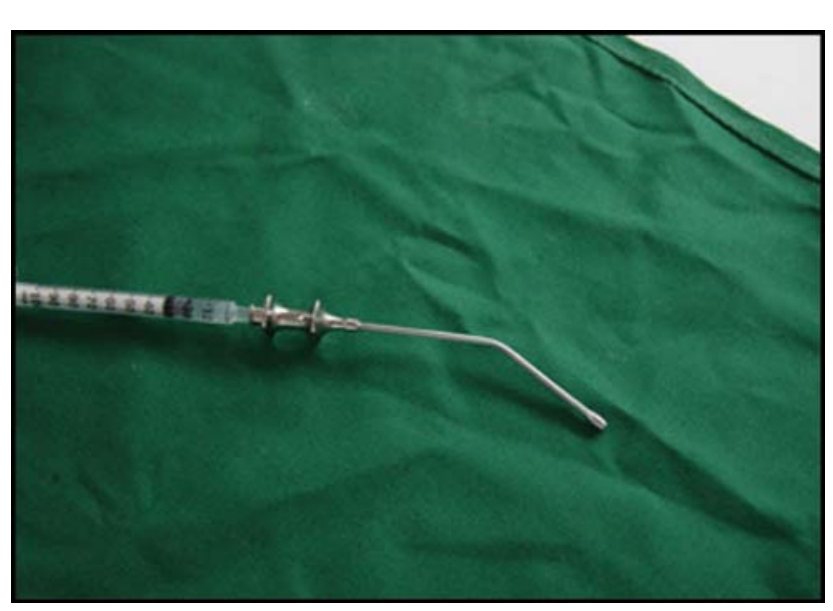

FIGURE 1 - Gavage tube used to administer the drugs.

\section{Histology and digital image analysis}

Three animals from each group were sacrificed at $3,7,10,14$, and 21 days after surgery. Incision areas were photographed on the day of surgery and on the day of sacrifice. The sites of the surgical incisions were removed, stretched onto cardboard strips, and preserved in $10 \%$ formalin. Specimens were mounted on slides and stained with hematoxylin-eosin for digital histomorphometry analysis. Images were captured with a 3 ccd pro series digital camera from Media Cybernetics (www.mediacy.com) using the Image Pro plus 4.5 software coupled to and Olympus Bx 50 microscope (Department of Morphophysiological Sciences, State University of Maringá, PR, Brazil). All images were capture at 400x magnification. In addition, since scar tissue was predominantly situated in the deep portion of the histological section, care was taken to ensure that all images were captured from this layer. Within each slide, regions showing the best image quality were selected. For quantification of cell number, masks were generated for all nuclei within any given image. In some cases, nuclei were manually selected to ensure that none had been omitted by the software. The software then generated cell counts based on these masks. The program was unable to distinguish cell types based on their morphological aspects, at times classifying 
polymorphonuclear cells with a semi-rounded shape as lymphomononuclear cells and at times classifying fibroblasts as polymorphonuclear cells. Thus, only total cell number was employed. For collagen quantification, all eosinophilic areas containing collagen were selected so that the software would mark the entire extension of collagen. The total area occupied by collagen fibers $\left(\mu \mathrm{m}^{2}\right)$ was calculated by the software based on the resulting masks. The percentage of the total image area occupied by collagen fibers was also calculated. A representative image of $\mathrm{H} \& \mathrm{E}$ stained tissue is shown in Figure 2. The corresponding computer-generated nuclear and collagen masks are shown in Figure 3 and 4, respectively.

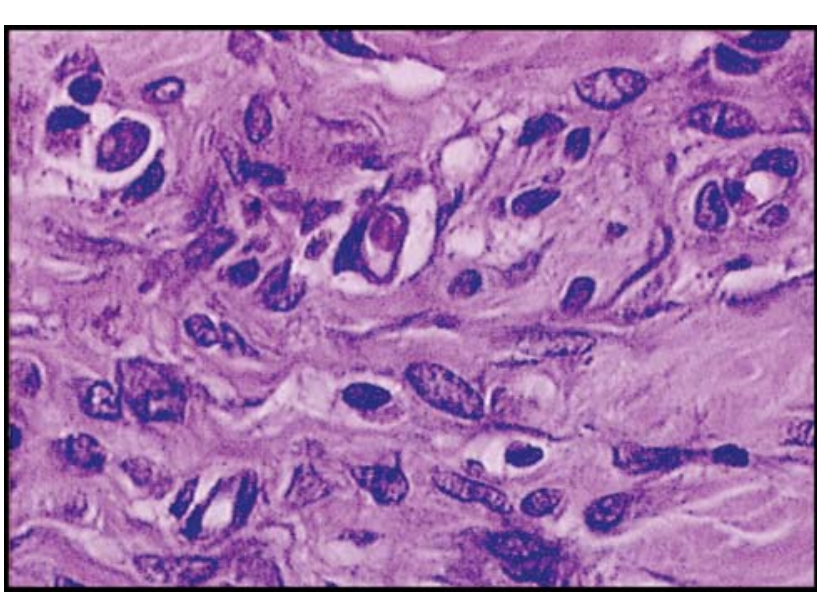

FIGURE 2 - Representative image of an H\&E-stained specimen obtained at postoperative Day 10 from a drug-treated animal (400x magnification).

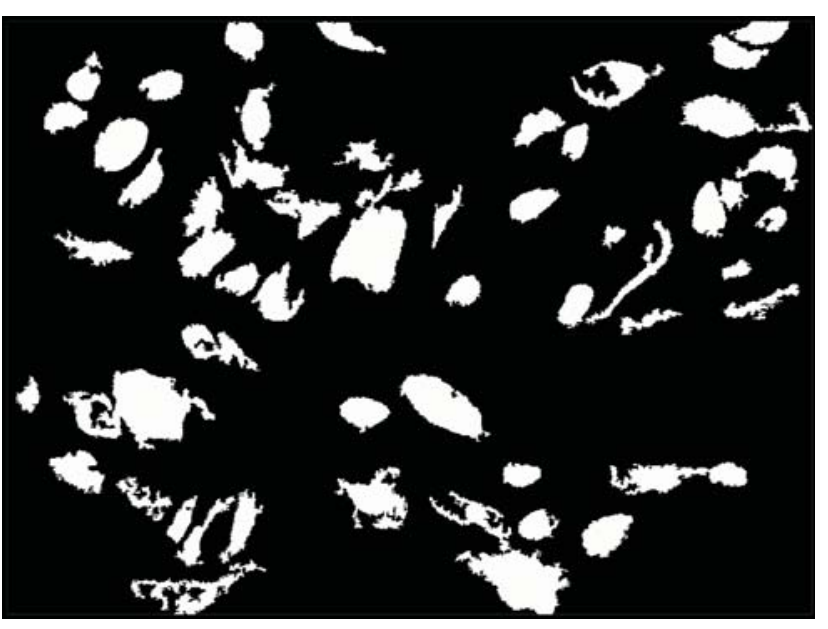

FIGURE 3 - Representative image of software-generated nuclear "masks." The masks were constructed from the image shown in Figure 2.

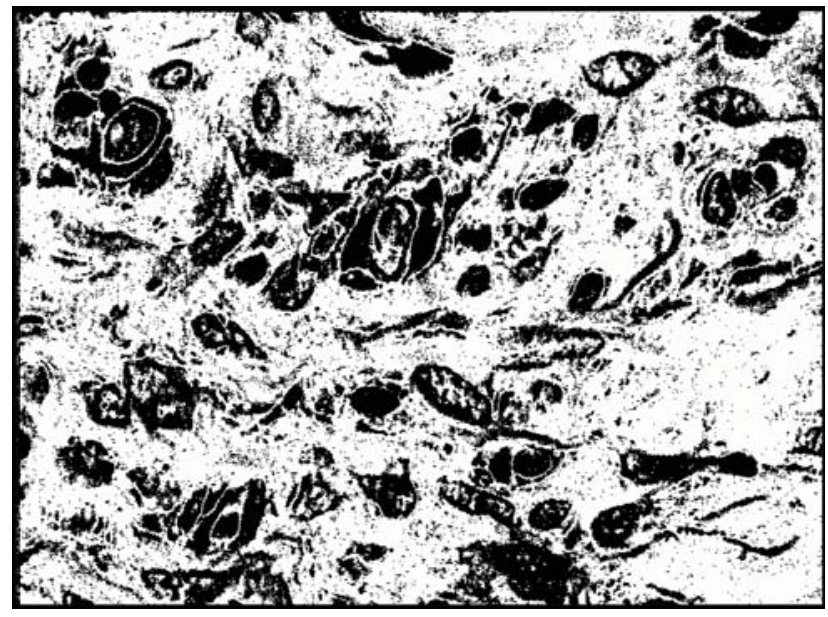

FIGURE 4 - Representative image of software-generated “masks" for collagen fibers. Masks were constructed from the image shown in Figure 2.

\section{Statistical analysis}

Descriptive statistics were generated for all results. In view of the nature of the data and of the study, no group comparisons were performed.

\section{Results}

All animals had a good course, with no clinical complications or deaths in either group. No differences in the macroscopic aspect of the scars were observed between either group. As shown in Figure 5, the absolute cell count in the inflammatory infiltrate was lower in the group receiving medication compared to control group at postoperative Day 7, 10, and 14.

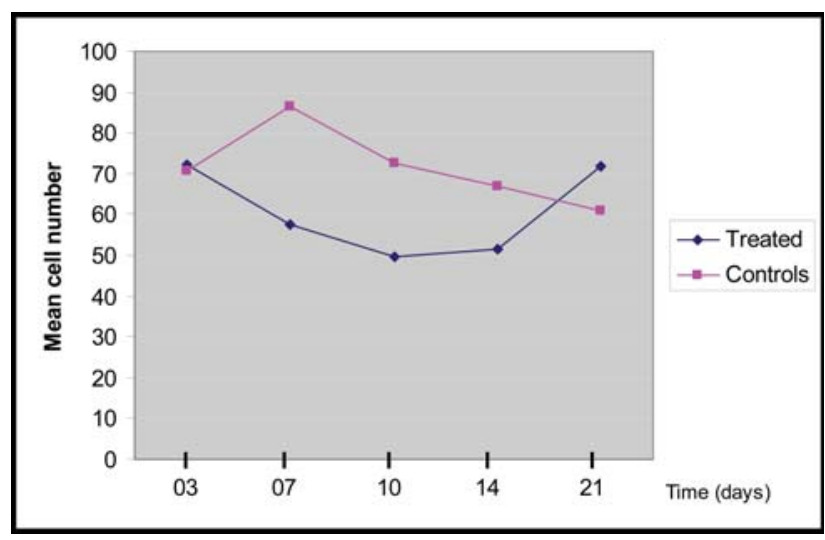

FIGURE 5 - Postoperative time-course of mean cell number at scar sites in animals treated with immunosuppressants (cyclosporine, azathioprine, and prednisone) and in untreated animals. Each data point represents the mean of three animals. 
At postoperative Day 21, this trend was no longer present (See also Table 1). The percentage of collagen fibers present in the scars was unaltered by immunosuppression up to the $10^{\text {th }}$ postoperative day. At Day 14, differences

TABLE 1 - Postoperative cell numbers at the scar site of immunosuppressant-treated and control rats.

\begin{tabular}{ccc}
\hline $\begin{array}{c}\text { Postoperative } \\
\text { Period } \\
\text { (Days) }\end{array}$ & $\begin{array}{c}\text { Numbers cells } \\
\text { (Treated) }\end{array}$ & $\begin{array}{c}\text { Numbers cells } \\
\text { (Controls) }\end{array}$ \\
\hline $\mathbf{3}$ & $66 ; 74 ; 77$ & $63 ; 67 ; 82$ \\
& $(\mathrm{~F}=72.33)$ & $(\mathrm{F}=70.66)$ \\
\hline $\mathbf{7}$ & $46 ; 57 ; 70$ & $72 ; 84 ; 103$ \\
& $(\mathrm{~F}=57.66)$ & $(\mathrm{F}=86.33)$ \\
\hline $\mathbf{1 0}$ & $48 ; 48 ; 53$ & $67 ; 67 ; 84$ \\
& $(\mathrm{~F}=49.66)$ & $(\mathrm{F}=72.66)$ \\
\hline $\mathbf{1 4}$ & $47 ; 48 ; 60$ & $60 ; 60 ; 81$ \\
& $(\mathrm{~F}=51.66)$ & $(\mathrm{F}=67.00)$ \\
\hline $\mathbf{2 1}$ & $57 ; 78 ; 80$ & $58 ; 59 ; 66$ \\
& $(\mathrm{~F}=71.66)$ & $(\mathrm{F}=61.00)$ \\
\hline
\end{tabular}

F= Mean

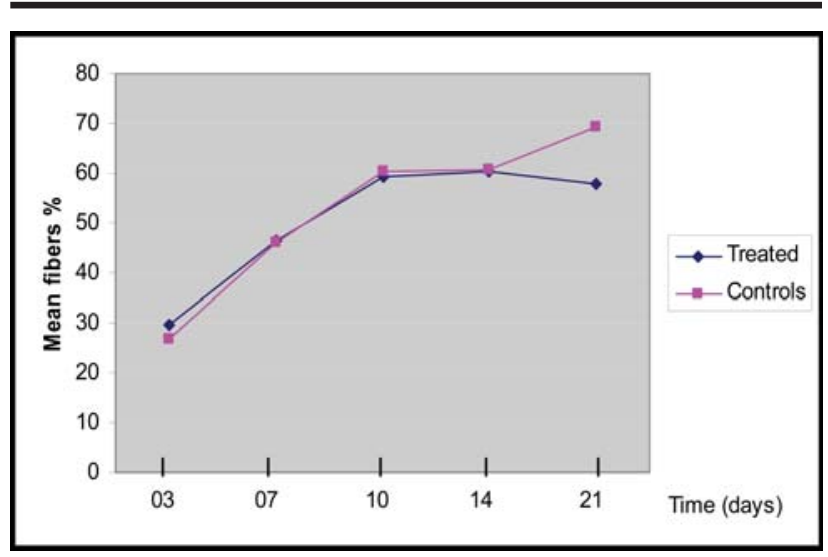

FIGURE 6 - Postoperative time-course of collagen fiber content at scar sites in animals treated with immunosuppressants (cyclosporine, azathioprine, and prednisone) and in untreated animals. Each data point represents the mean of three animals.

\section{Discussion}

Here, we have developed an animal model to study the effects of immunosuppression on the cutaneous wound healing using a triple drug scheme. Both male and female rats were used since the goal was to implement the model and not to statistically evaluate differences in the healing process or gender-related susceptibility to the action of immunosuppressive drugs. Moreover, isogenic animals were employed with the intent of performing future investigations of the action of immunosuppressive drugs in allotransplant models. Advantages of using rats include their small space between the two groups began to emerge, albeit only among a few individual animals. At Day 21, a trend towards an increased percentage of fibers in the control group was clearly present (Table 2 and Figure 6).

TABLE 2 - Postoperative collagen fiber content at the scar site of immunosuppressant-treated and control rats.

\begin{tabular}{ccc}
$\begin{array}{c}\text { Postoperative } \\
\text { Period } \\
\text { (Days) }\end{array}$ & $\begin{array}{c}\text { \% Collagen } \\
\text { (Treated) }\end{array}$ & $\begin{array}{c}\text { \% Collagen } \\
\text { (Controls) }\end{array}$ \\
\hline $\mathbf{3}$ & $\begin{array}{c}23.06 ; 31.23 ; 35.00 \\
(\mathrm{~F}=29.76)\end{array}$ & $\begin{array}{c}16.15 ; 31.42 ; 32.29 \\
(\mathrm{~F}=26.62)\end{array}$ \\
\hline $\mathbf{7}$ & $\begin{array}{c}41.58 ; 47.56 ; 50.12 \\
(\mathrm{~F}=46.42)\end{array}$ & $\begin{array}{c}36.65 ; 50.02 ; 51.69 \\
(\mathrm{~F}=46.11)\end{array}$ \\
\hline $\mathbf{1 0}$ & $\begin{array}{c}50.93 ; 63.53 ; 63.81 \\
(\mathrm{~F}=59.42)\end{array}$ & $\begin{array}{c}56.13 ; 57.61 ; 67.87 \\
(\mathrm{~F}=60.53)\end{array}$ \\
\hline $\mathbf{1 4}$ & $52.82 ; 62.15 ; 66.09$ & $55.31 ; 60.01 ; 67.18$ \\
& $(\mathrm{~F}=60.35)$ & $(\mathrm{F}=60.83)$ \\
\hline $\mathbf{2 1}$ & $50.66 ; 60.55 ; 62.90$ & $66.40 ; 66.97 ; 74.42$ \\
& $(\mathrm{~F}=58.03)$ & $(\mathrm{F}=69.26)$ \\
\hline
\end{tabular}

$\mathbf{F}=$ Mean

requirements, minimal staff requirements, low cost, and rapid reproduction rates. The convenient size (compared to mice) and rusticity of these animals (i.e., resistance to infections and tolerance to surgery and anesthesia) justify their choice for models such as this one. The feasibility of this newly developed model is enhanced by the simple surgical techniques and their low morbidity and cost. Administration of drug therapy by gavage was performed to simulate the oral route, of these medications in humans. More importantly, the triple immunosuppressive scheme employed was based on protocols used world-wide for the treatment of rejection in renal transplant recipients. Further refinement of this model will require a dose titration study to determine drug serum levels among animals with the goal of achieving "ideal doses." Although a combination of three agents was employed here, there is evidence to suggest that immunosuppressants are effective when administered separately by the oral route ${ }^{3,4}$. On the other hand, Einsinger ${ }^{5}$ observed that cyclosporin did not delay cutaneous and fascial muscle healing in rats. A combination of azathioprine and prednisone delayed cutaneous healing on the 8th postoperative day, although this effect then disappeared within $7 \mathrm{~d}$. Pedersen ${ }^{6}$ demonstrated that the use of a triple immunosuppression scheme similar to that used here (cyclosporin, azathioprine and prednisone) had protective effects on the central nervous system of rats submitted to xenografts. Computerized histomorphometric studies similar to that performed here have been reported. Moreso $^{7}$ successfully employed histomorphometry to evaluation interstitial cortical volume in human renal biopsies. Also, Silva $\mathrm{Jr}^{8}$. studied bone regeneration after 
surgically-introduced defects in the femur. In the present study, the use of Image Pro Plus 4.5 software proved to be effective for histological analyses. This method minimizes the factors that usually introduce error when carrying out visual counts using light microscopy and permitted a precise quantification of collagen fibers. A future goal is to refine this method to qualitatively assess cell infiltrate. The results obtained here suggest that immunosuppressive drugs act on cutaneous healing by altering cell number and collagen fiber content at the inflammatory site. Cellular responses occurred on postoperative Day 7-10 and persisted until Day 14. At Day 21, these effects could no longer be observed. These results suggest that these drugs act during the initial phases of the healing process when a larger number of cells are involved. The effect of immunosuppression on the formation of collagen fibers manifests on Days 1014 and is most apparent at Day 21. It is possible that alterations in cellular responses (inflammatory reaction) occur on a short-term basis, and these changes in the cell population have a delayed effect on the amount of collagen produced. It is probable that, in view of the repair efforts elicited by the surgical incision, immunosuppression acted by reducing the number of cells involved in the healing process through inhibition of chemical mediators ${ }^{1}$.

\section{Conclusion}

The experimental model developed here reproduces the immunosuppressive drug route and regimen used in human patients and has several characteristics that that lend to its feasibility, including its low cost, reproducibility, and ease of use. Future refinements, including qualitative analysis of cell infiltrate using the computerized morphometric system, will yield a more powerful tool for the investigation of the effects of immunosuppressants or other drug classes on wound healing.

\section{References}

1. Modolin MLA. Biologia da cicatrização dos tecidos. In Melega, Zanini, Psillakis. Cirurgia plástica reparadora e estética. $2^{\text {a }}$ ed. Rio de Janeiro: Medsi 1992; 9-13

2. WHO Chronicle. 1985; 39(2):51-6

3. Calne RY, White DJG, Rolles K, Smith DP, Herbertson RM. Prolonged survival of pig orthotopic heart grafts whith cyclosporin A. Lancet. 1978; 2:1181-7.

4. Homan WP, Fabre JW, Williams KA, Millard PR, Morris PJ. Studies on the immunosuppressive properties of cyclosporin A in rats receiving renal allografts. Transplantation. 1980; 29:361-8.

5. Einsinger D R, Sheil A G. A comparison of the effects of cyclosporin A and standard on primary wound healing in the rat. Surg Gynecol Obstet. 1985; 160:135-8.

6. Pedersen EB, Zimer J, Finser B. Triple immunosuppression protects murine intracerebral, hippocampal xenografts in adult rat hosts: effects on cellular infiltration, major histocompatibility complex antigen induction and blood-brain barrier leakage. Neuroscience. 1997; 78: 685-701.

7. Moreso F, Gratin J, Vitriá E, Condom R, Poveda JM. Automatic evaluation of renal interstitial volume fraction. Transplant Proc. 1995; 27: 2231-2.

8. Silva AN Jr, Pinheiro ALB, Oliveira MG, Weismann R, Ramalho LMP, Nicolau RA. Computerized morphometric assessment of the effect of low-level laser therapy on bone repair: an experimental animal study. J Clin Laser Med Surg. 2002; 20:83-7.

\section{Correspondence:}

Antonio Chiquetti Júnior

Rua Paes Leme, 1264 / sala 601

86010-610 Londrina - PR Brazil

Phone: (55 43)3324-3808

chiqueti@sercomtel.com.br
Conflict of interest: none Financial source: none

Received: March 12, 2007

Review: May 14, 2007

Accepted: June 15, 2007

\section{How to cite this article}

Chiquetti Jr A, Rodrigues MAF, Delfino VDA. Proposal of an experimental model for the study of the effects of drugs on cutaneous healing. Acta Cir Bras. [serial on the Internet] 2007 July-Aug;22(4). Available from URL: http://www.scielo.br/acb 